RESEARCH ARTICLE

\title{
Thomas Southerne's Muslim Settings and the Politics of the Succession Crisis: A Critical Study of The Loyal Brother
}

Met'eb Ali Alnwairan

English Section, Department of Foreign Languages, University of Nizwa, Sultanate of Oman

\begin{abstract}
This paper argues that Thomas Southerne used Muslim characters and settings in his play The Loyal Brother (1682) as an allegory for the Succession Crisis of the Restoration period in England. As Southerne's play was published during a time of extreme political tension and controversy, the political discourse the playwright presents in his work reflects the increasing partisanship in the English political nation. In a sense, the representations of Muslim characters in Southerne's play were heavily influenced by the contemporary politics of Restoration England. Obviously, a Tory writer like Southerne employed the image of the Muslim character to emphasize pro-Stuarts political ideas.
\end{abstract}

Keywords: Thomas Southerne, The Loyal Brother, Succession Crisis, Restoration Drama

\section{Introduction}

Thomas Southerne is one of the Restoration playwrights who used the characters and plot of his plays as allegories for relevant internal political issues in England. Southerne was so active during a time of high political tension and dispute between different political parties. Consequently, Southerne presented a political discourse in his works that reflected the growing partisanship in the English political nation. In fact, the representations of Muslim characters in Southerne's The Loyal Brother were heavily influenced by the contemporary political life in Restoration England.

The topics discussed in the plays written Southerne are key points in understanding the interplay between playwrights' treatment of Muslim characters on stage and the contemporary ideology of the age $^{1}$. In fact, the political unrest that resulted from the debate over the succession issue revealed a general tendency to use more geopolitically distant figures and plots, specifically ones with Oriental Muslim settings, to comment on one of the major crises of the Restoration period. English playwrights, like Southerne, employed this coded discourse in their attempts to implicitly deliver advice, criticism, and commentary on the major concerns of the political nation. his study examines how Restoration playwrights used their historical Muslim sources both to heroicize or demonize certain Restoration

\footnotetext{
${ }^{1}$ For more about the treatment of Muslim characters on the Restoration political stage see M. Alnwairan's "Muslims and Political Allegory in Elkanah Settle's The Heir of Morocco."
} 
political figures, and, at the same time, to distance themselves from any hostile reactions by their political opponents. The complex parallels the playwright established between the crises in Islamic countries and England's succession crisis were still clear enough to be understood by the majority of Restoration spectators who were used to make connections between dramatic production and the contemporary political scene of their time. As Orr (2001) explains, Restoration audiences "expected heroic poems to be allegorical, offering several layers of meaning," and this supports the view in this dissertation that Restoration theatregoers recognized the fact that such works contained more than its surface meaning (p. 11). In fact, English playwrights found in Muslim settings and characters a perfect subject matter that could be compared to contemporary political and religious scenarios. The instability in the Muslim states' ruling institutions that the plays represented served as a good analogy for contemporary English political life.

Thomas Southern was born in Dublin in the year of the Restoration of Charles II. He attended Trinity College, Dublin University in 1675 but never received a degree. At the age of 20, young Southerne traveled to London to try his fortune as a writer. Southern quickly found his way to the stage and established connections with James the Duke of York (Dodds, 1976, pp. 4-5). The elaborate praise Southerne paid to the Duke in The Loyal Brother showed the strong relationship between the two. When the Duke of York came to power in 1685, he rewarded Southerne for his faithful efforts and loyalty. Interestingly, Southerne joined the cause of James in arms as in words. He had paused his career in playwriting and enlisted in James's forces that subdued Monmouth's rebellion the same year (Jordan and Love, 1988, p. xv). Southerne reached the peak of his success as a dramatist in the late 1690s after producing a number of popular plays like The Fatal Marriage, or The Innocent Adultery (1694) and Oroonoko, or The Royal Slave (1696). Unlike the quarrelsome Settle, Southerne gained the respect of Whig and Tory noblemen and writers alike (Dodds, 1976, p. 11). John Dryden was a close friend to Southerne and supported the young writer by writing prologues and epilogues to some of his plays. Pope and Swift praised Southerne's talents and paid him compliments on several occasions (Jordan and Love, 1988, p. xxxii).

Southerne was engaged in the political life of London very early in his life. He was only 21 years old when he produced his first dramatic work, The Loyal Brother. The play was not a great success, but it attracted Tories for its praise of the Duke of York. The fierce anti-Whig sentiment in the Prologue and the emphasis on the legitimacy of James's right of the natural succession made the play popular among Tories.

\section{The Loyal Brother (1682)}

The plot of the play revolves around the conspiracies against Tachmas, the noble brother of Seliman, the Sophy of Persia. Problems start when the royal brothers fall in love with the fair Semanthe, who reciprocates love to Tachmas only. As a result, Seliman grows jealous of his brother. The evil Ismael and Arbanes, who feel threatened by Tachmas successes, plot together to destroy the noble prince. Sunamire, Arbanes's sister, opens a third front against Tachmas when she discovers that the prince favors Semanthe over her. Ismael persuades Seliman to kill his brother in order to win Semanthe's 
love. Tachmas is saved at the last moment by Semanthe and Begona, the queen mother. However, the conspirators do not give up. They forge a letter that tells of Tachmas's plans to murder the Sophy and usurp the Persian throne. The Sophy imprisons Tachmas as a result. Semanthe joins her lover in prison and chooses to face the same destiny. A faithful friend of Tachmas discovers Sunamire and Arbanes's plan to poison the lovers, and switch the poisoned bowls labels. Therefore, the plotters drink the poison they have prepared for the lovers. Before dying, they confess to Seliman Ismael's role in the plot. Seliman orders Ismael to death, and the play ends with the joyous union of Tachmas and Semanthe.

Political polemics are present early on in the play. In the Prologue to the play, which was prepared by John Dryden, sentiments of political partisanship are obvious. Dryden attacks Whigs by the means of making a comparison between the practices of Whigs and those of critics. Dryden's lines deserve to be quoted at length since they tell much about Tory political themes and tropes used in attacking their Whig rivals.

Poets, like Lawful Monarchs, rul'd the Stage,

Till Criticks, like Damn'd Whiggs, debauch'd our Age.

Mark how they jump: Criticks wou'd regulate

Our Theatres, and Whiggs reform our State:

Both pretend love, and both (Plague rot 'em) hate.

The Critick humbly seems Advice to bring,

The fawning Whigg Petitions to the King:

$[$.

Criticks wou'd starve the Poet, Whiggs the Prince.

The Critick all our troops of friends discards;

Just so the Whigg wou'd fain pull down the Guards. (Prologue pp. 1-13)

The prologue satirizes the pope-burning pageants, a Whig favorite political activity during the Exclusion Crisis period. In fact, Dryden mocks the absurdity of Whig pageants per se: "Alas, what's one poor Pope among 'em all!/ He burns; now all true hearts your Triumphs ring:/ And next (for fashion) cry, God save the King" (Prologue, pp. 38-40).

The Epilogue is no less aggressive towards Whigs. It combines anti-Whig ideas with a comment on foreign policy issues. Dryden, also its writer, alludes to the oppression of Protestants in England's Catholic neighbor, France,

Of this damn'd grievance ev'ry Whigg complains;

They grunt like Hogs, till they have got their Grains.

Mean time you see what Trade our Plots advance,

We send each year good Money into France:

And they, that know what Merchandise we need,

Send o're true Protestants, to mend our breed. (Epilogue, pp. 35-40) 
Dryden's lines make it hard to miss the political projections in the play as his lines prepare for bolder political criticism of his rivals in the opposition and in the Whig party. The play itself proves to be politically charged, too. Southerne, unlike Dryden, puts certain political figures under his microscope. For each party, he portrays a model character who shows typical traits of his party or supporters. For example, the character of Tachmas stands as a good example of the Tory's typical depiction of the Duke of York. During the early 1680s, the Duke was deprived of much of his privileges while his brother, the king, was not completely happy with his presence in London. This resulted in further agitating the suspicious Anglican majority in the Parliament. During the late 1670s and early 1680s, many attempts were made to prevent the Duke from ascending to the throne after the death of Charles II. The play reflects such malicious schemes and highlights the eventual triumph of the legitimate heir. For that end, Southerne's play places great emphasis on Tachmas's military prowess and proficiency. Osman, a captain in the Persian army, narrates the good news to the Sophy about the recent victory of Tachmas,

And when fame calls your Armies to the field,

May Tachmas lead 'em out, and still return

As now, triumhant home,

In all the glories of a famous War. (I.i 6) ${ }^{2}$

Loyalty is Tachmas's major characteristic in the Southerne's play. Tachmas stays loyal to his king and brother even when he is sentenced to death. In more than one scene in the play, Tachmas urges his captains and soldiers to keep loyal to their king since loyalty is the key concept in a soldier's code. In fact, Tachmas's instructions to his fellow soldiers when he bids them farewell can be understood as an embedded request to the audience to remain loyal to the Stuart monarchy. Tachmas declares,

And now, my friends, part we like Soldiers here;

All to our several fates: fight for the King,

As I have done, and may your services

Be better paid.

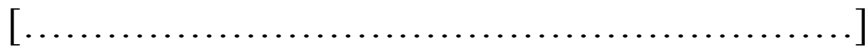

And now a long farewel: live to enjoy

A better fortune in your Princes favour. (III.ii 29)

In Thomas Southerne: Dramatist John Dodds (1976) points out that Southerne used this picture of perfection and loyalty in order to defy all reports of James's treachery and to present him as a the only trusted candidate to the English throne (p. 38).

Interestingly enough, the phraseology Southerne uses in his play is strongly connected to what James experienced during the tense years of his exile. In the early 1680s, Charles II deprived his brother of the public offices he had held earlier. It is not a mere coincidence that Southerne portrays a similar

\footnotetext{
2 This text is taken from Early English Books Online edition of the play. All subsequent references to this text will be cited parenthetically by (act, scene, and page number.)
} 
scene in which the Sophy banishes his brother and deprives him of his offices. The angry Sophy addresses his brother as follows:

But fly, be gone to death, or banishment;

And all the publick offices you held

By our permission, here we take agen:

The general staff, Arbanes, now is thine. (II.iv 23)

The other major character that carries political weight in the play is the character of the villain Ismael. Jordan and Love (1988) argue that Southerne alludes to the Whig leader Shaftsbury through the negative portrait of Ismael (p. 4). In harmony with typical Tory allegorical depictions of Shaftesbury, the character of Ismael is an extreme example of treachery and malice. The parallels between Ismael and Shaftsbury are numerous. One of these parallels is that both of Ismael and Shaftsbury are deposed favorites who recently lost their high ranks. Shaftsbury, like Ismael, was removed from his position as President of the Privy Council in 1679. In addition, Ismael, just like Shaftsbury, shows great ability to control the masses, make plots, and fabricate charges. While doing so, Ismael is always careful not to raise suspicions about his activities. Simultaneously, Ismael expresses his wish to have a fail-proof revenge against Tachmas. In a dialogue with Sunamire and Arbanes he explains,

Long have, I waited time, and now it comes,

The Golden minute comes, that offers us

A safe revenge, but mounted on the wing:

Say Sunamire, Arbanes, shall it pass

Unheeded like the common births of time? (I.i 10)

Southerne's play sheds light on many other political activities of Ismael, especially his role in agitating people against their monarch. Ismael proves to be an expert in rabble-rousing, a prominent Whig vice in the Tory political canon (Owen, 1996, pp. 149-151). Ismael gathers people around him and works his arts on them,

... some friends I've made

Already there, brave factious, gifted Rogues,

That Cant their Doctrine to their present wants,

And Zealously, upon a fit of Conscience,

Sin or Unsin Rebellion to the Croud:

These are the fittest instruments to gull

The easie people: hark, the Monster roars!

[Shoots within]

The Rable is assembled to my wish;

This is the time, to work 'em. (V.i 45)

Ismael knows that agitating the rabble will enable him to mount the populist wave. He explains to his fellows that "Whilst we, like Sailers tacking for the wind, / Mount on the deck at last, with full blown 
sails/ Drive onward to our Port ..." (III.iii 31). Obviously, Ismael uses quite a similar terminology to that used by Whig political leaders in the mass demonstrations they organized during the late 1670s and early 1680s. During that period, Susan Owen explains, Whig political propaganda called intensively for protecting the liberty of the English people, their beliefs, and their very Englishness against popery and foreign interference (1996, p. 111). Ismael, in front of the mob he arouses, calls for quite similar values:

If to defend your Lives, your Liberties,

Your Laws, your Customes, and your ancient dues,

Be to rebel, then this is rank Rebellion:

But sure a just defence may hope a fairer name. (V.ii 49)

Later on, Ismael calls on the people to stand "against this barbarous, inhumane King, / That grows in tyranny" (V.ii 49). The rabble is quickly influenced by Ismael's fiery speech and calls "Rebellion or nothing, Rebellion or nothing" and " No, no; we'r all for Rebellion" (V.ii 49). It is noteworthy here to refer to Owen's argument that Southerne associated the corruption of court with rebel noblemen in an attempt to defy the Whig assertion that the source of corruption at court was always the king himself (1996, p. 131). Ismael confesses that "The court has been my Sphear,/ Where, with the musick of my tongue in counsel, / I've charmed opinion after me" (I.i 9).

Following the Tory tradition of attacking certain Whig practices and traits, Southerne's play emphasizes the destructive effects of ambition on the individual and the group. In a similar fashion to Whitaker's The Conspiracy, characters in The Loyal Brother refer to ambition as a source of rebellion and disloyalty that usually lead individuals to extremes. Ismael declares: "Ambition is our Idol, on whose wings/ Great minds are carried only to extreams;/ To be sublimely great, or to be nothing" (I.i 12). Tachmas highlights the ill effects of ambition on people too,

O ambition!

How strangely dost thou charm the minds of men!

That they will choose to starve on mountain tops,

Rather than taste the plenty of the Vale. (III.ii 28)

Southerne's play, while paying praise to the Duke of York, shows signs of criticism of his brother, King Charles II. The portrayal of Seliman provides a means of commenting on Charles political practices that sometimes upset all, Tories and Whigs. Southerne exposes Charles's follies by alluding to Seliman's unwise and rash reactions and policy. In the play, the Sophy admits to his lack of good councilors who can help him manage the concerns of his vast empire,

The Court is in an uproar with my follies

Expos'd in publick; all my Friends stand mute

Before me, not a Counseller that dares

Advise me, even flattery is dumb. (II.iii 17)

The Sophy's words reflect the fact that all the private issues of his court were no longer private. This allegorical representation of Charles's court could be hardly missed by an audience used to the heavy use 
of stage political allegories. Charles's II reign witnessed an eruption of the private into the public. For instance, news about the king's sexual relations, his mistresses, his illegitimate offspring were topics of conversations at London's coffee-houses. Tachmas also comments on the general situation at court, "the Court seems all a crowded Wilderness" (IV.i 38). In fact, the Sophy himself is to be blamed for all of the chaos. He proves to be a naïve and narrow-minded ruler. Ismael sees him as,

[...] of a nature hot,

Vain, and ambitious; yet withal most pliant,

And easie for the flatterer to mould

To any form; so Jealous of his glory. (I.i 11)

Nevertheless, the Sophy learns a lesson by the end of the play. The Sophy while blessing the marriage of Tachmas and Semanthe declares,

Take her, and wear her ever in thy heart:

Whilst I collected in my temper stand,

And may succeeding Monarchs learn from me,

How far to trust a Statesmans policy. (V.ii 58)

Southerne polishes his portrayal of Seliman by the end of the play when he presents the Sophy as generous and noble. The Sophy abandons his jealousy and stubbornness and blesses the reunion of Tachmas and Semanthe.

The modifications that Southern made to his play are worth some consideration. The play is based on a French turquerie (Oriental tale) entitled Tachmas Prince de Perse. The tale was published in Paris in 1676 and translated into English by Peter Porter the same year (Dodds, 1976, pp. 31-2). Nevertheless, Southerne departed widely from the French version of Tachmas's story. While Tachmas and Semanthe are united in Southerne's play, the royal couple faces a tragic end in the source tale. In fact, Southerne made such modifications to his play because he tried to make his characters better matches to the figures he intended to dramatize. The political charged messages that the playwright intended to convey led him to produce a revised version of the story of Tachmas.

\section{Conclusion}

In conclusion, Southerne employed Muslim characters and settings in his play mainly to speak of his political positions and beliefs. The contemporary stage served as a perfect arena for both Whigs and Tories who aimed to express and spread certain political ideas and views. The topics discussed in the play are key points in understanding the interplay between the English playwrights' treatment of Muslim characters on stage and the contemporary ideology of the age. In fact, Southerne's literary production during the long and fierce controversy over the succession issue revealed the general tendency to use allegorical figures and plots to comment on one of the major crises of the Restoration period. Restoration playwrights, like Southerne, used complex political allegories that were based on Oriental Muslim settings. This allegorical discourse enabled the playwrights to deliver advice, criticism, and commentary on the major concerns of the political nation. Restoration playwrights used their historical 
sources both to heroicize or demonize certain Restoration political figures and, at the same time, to distance themselves from any hostile reactions by their political opponents. In general, Restoration playwrights preferred to free themselves from the cultural specificity of Islamic culture rather than be involved in the complicated classic dialogues with the "Other" which would drive them away from their political agendas they intended to express in the first place. Among the main concerns of Southerne's play are good political systems, honest monarchs, and a better practice of politics and religion.

\section{References}

[1] Alnwairan, M. (2020). Muslims and political allegory in Elkanah Settle's The Heir of Morocco. Millennium Journal of Humanities and Social Sciences, 1(1), 10-19. https://doi.org/10.47340/mjhss.v1i1.2.2020

[2] Dodds, J. (1970). Thomas Southerne: Dramatist. Yale UP.

[3] Jordan, R, and Harold L. (Ed.). (1988). The works of Thomas Southerne. Clarendon Press.

[4] Orr, B. (2001). Empire on the English stage: 1660-1714. Cambridge UP.

[5] Owen, S. (1996). Restoration theatre and crisis. Clarendon Press.

[6] Southerne, T. The Loyal Brother. (1682). Early English Books Online Text Creation Partnership, 2020. https://quod.lib.umich.edu/e/eebo/A60961.0001.001?v iew=toc. 